\section{A List of Germplasm Releases from the University of Wisconsin Carrot Breeding Program, 1964-1994}

\author{
I.L. Goldman ${ }^{1}$ \\ Department of Horticulture, University of Wisconsin-Madison, 1575 Linden \\ Drive, Madison, WI 53706
}

The carrot (Daucus carota L.) breeding program at the Univ. of Wisconsin-Madison was initiated by W.H. Gabelman in 1949. A variety of inbred lines, hybrids, and synthetic populations were released by Gabelman through the Wisconsin State Agricultural Experiment Station over 30 years. Many of these lines and synthetics have served as germplasm sources for processing carrot hybrids developed and grown throughout the world. In some

Received for publication 31 July 1995 . Accepted for publication 28 Mar. 1996. The cost of publishing this paper was defrayed in part by the payment of page charges. Under postal regulations, this paper therefore must be hereby marked advertisement solely to indicate this fact.

${ }^{1}$ Assistant Professor of Horticulture. cases, these inbred lines have been used directly to produce commercial hybrids used widely in the processing industry. In other cases, this germplasm has served as parental material for breeding efforts.

The breeding program was geared toward assessing the feasibility of $F_{1}$ hybrid carrots, which required an understanding of pollen sterility, inbreeding potential, and seed production characteristics. The primary focus of the breeding program was the development of disease resistant, high-carotene, high-quality processing carrot inbred lines and populations for use in the commercial seed industry. All sterile lines were developed through the use of petaloid sterility, with the exception of W93A, which was developed with brown anther sterility. Between 1953 and 1981, Gabelman and students investigated the inheritance of caro- tene and color, pollen sterility, and resistance to cercospora leaf spot. This work assisted in the development of strategies crucial to the continued improvement of carrots through hybrid cultivars.

The primary types of carrot used in Gabelman's breeding program were 'Danvers', 'Red-Cored Chantenay', 'Royal Chantenay', and 'Nantes'. Many of the later inbred lines are of a type intermediate between 'Danvers' and 'Nantes'. These later lines possess the ability to be used in both fresh-market and processing pedigrees.

Little description, other than that found in brief release notices, has been available for distribution to workers in the field of carrot breeding and genetics. This report is an attempt to present a compilation of Gabelman's releases, including the year of release, line designation, salient features, and pedigree (Table 1). This report is one of a series that lists W.H. Gabelman's vegetable releases (Goldman, 1996a, 1996b).

\section{Literature Cited}

Goldman, I.L. 1996a. A list of germplasm releases from the University of Wisconsin onion breeding program, 1957-1993. HortScience 31:878879.

Goldman, I.L. 1996b. A list of germplasm releases from the University of Wisconsin table beet breeding program, 1964-1992. HortScience $31: 880-881$.

Table 1. Year of release, name or number, description and pedigree of carrot germplasm released by W.H. Gabelman, 1964-94.

\begin{tabular}{|c|c|c|c|}
\hline $\begin{array}{l}\text { Year of } \\
\text { release }\end{array}$ & $\begin{array}{c}\text { Name or } \\
\text { no. }\end{array}$ & Description $^{2}$ & Pedigree \\
\hline$\overline{1964}$ & $\mathrm{~W}^{2} \mathrm{~A}^{\mathrm{y}}, \mathrm{W} 93 \mathrm{~B}^{\mathrm{x}}$ & Inbred, brown-anther-sterile & $\begin{array}{l}\text { Derived from 'Royal Chantenay’. } \\
\text { Sterility derived from ‘Tendersweet' } \\
\text { obtained from J.E. Welch, Univ. of } \\
\text { California, Davis }\end{array}$ \\
\hline 1964 & Hybrid Gold & $\begin{array}{l}F_{1} \text { hybrid; large, deep, orange-colored } \\
\text { roots }\end{array}$ & W93A x Wissyn 33 \\
\hline 1964 & Wissyn 5 & $\begin{array}{l}\text { Synthetic, long, large wedge-shaped root; } \\
\text { increased carotene content }\end{array}$ & Derived from 'Kieler's Rote' \\
\hline 1964 & Wissyn 6 & $\begin{array}{l}\text { Synthetic, medium-length, wedge-shaped } \\
\text { root; good eating quality }\end{array}$ & $\begin{array}{l}\text { Derived from a cross of inbred lines } \\
\text { extracted from 'Kieler's Rote' and } \\
\text { 'Royal Chantenay' }\end{array}$ \\
\hline 1964 & Wissyn 33 & $\begin{array}{l}\text { Synthetic, medium-length, wedge-shaped } \\
\text { root }\end{array}$ & $\begin{array}{l}\text { Derived from inbred lines extracted from } \\
\text { a breeding line and the cultivars } \\
\text { Kieler's Rote and Tendersweet }\end{array}$ \\
\hline 1964 & Wissyn 171 & $\begin{array}{l}\text { Synthetic, long, tapered shape with } \\
\text { tapered tip }\end{array}$ & $\begin{array}{l}\text { Derived from inbred lines extracted from } \\
\text { 'Yellow Belgian' and 'Imperator' }\end{array}$ \\
\hline 1964 & Wissyn 173 & Synthetic, similar to Wissyn 171 & $\begin{array}{l}\text { Derived from inbreds extracted from } \\
\text { 'Imperator' }\end{array}$ \\
\hline 1971 & W77C ${ }^{w}$ & $\begin{array}{l}\text { Inbred, Nantes shape, uniform color, } \\
\text { combines well with W133 }\end{array}$ & $\begin{array}{l}\text { Derived from 'Scarlet Nantes' (Northrup } \\
\text { King) }\end{array}$ \\
\hline 1971 & W133A, W133B & $\begin{array}{l}\text { Inbred, uniform color, irregular cambium, } \\
\text { low incidence of cracking, smooth } \\
\text { exterior, uniform interior color }\end{array}$ & Derived from a single plant of Wissyn 33 \\
\hline 1971 & W204C & Inbred, large diameter, deep-orange color & $\begin{array}{l}\text { Derived from a pollination cage } \\
\text { containing } 10 \text { high-color lines. The } \\
\text { female parent was obtained from No. } 4 \\
\text { Sib-bulk Mass. This synthetic was } \\
\text { derived partially from 'Danvers } 126 \text { ' } \\
\text { developed by the Campbell Soup Co. }\end{array}$ \\
\hline 1971 & Lucky Gold & $F_{1}$ hybrid, Nantes shape & $\mathrm{W} 133 \times \mathrm{W} 77 \mathrm{C}$ \\
\hline 1971 & Danvers Gold & $F_{1}$ hybrid, Danvers shape & W133 x W204C \\
\hline 1988 & W255A, W255B & Inbred, excellent color and flavor & $\begin{array}{l}\text { Derived from the synthetic } \\
\text { population RZT } 75^{\vee} \text { selected for } \\
\text { resistance to rhizoctonia }\end{array}$ \\
\hline
\end{tabular}


Table 1. Continued.

\begin{tabular}{|c|c|c|c|}
\hline $\begin{array}{l}\text { Year of } \\
\text { release }\end{array}$ & $\begin{array}{l}\text { Name or } \\
\text { no. }\end{array}$ & Description $^{2}$ & Pedigree \\
\hline 1988 & Lucky B & $\begin{array}{l}\mathrm{F}_{1} \text { hybrid, low in terpenoids, carotene } \\
\text { level twice that of Scarlet Nantes, } \\
\text { excellent flavor }\end{array}$ & W259 x W266 \\
\hline 1994 & WAY271B & $\begin{array}{l}\text { Inbred, aster yellows resistant, deep- } \\
\text { orange color, moderate resistance to } \\
\text { foliar blights }\end{array}$ & $\begin{array}{l}\text { Derived from an aster yellows-tolerant } \\
\text { selection from the OP cultivar Gold } \\
\text { King crossed with the synthetic } \\
\text { AYSYN83, followed by recombination } \\
\text { with selections from AYSYN83 }\end{array}$ \\
\hline 1994 & WAY272C & $\begin{array}{l}\text { Inbred, aster yellows resistant, } \\
\text { good resistance to foliar blights }\end{array}$ & $\begin{array}{l}\text { Derived from an aster yellows-tolerant } \\
\text { selection of an inbred line derived from } \\
\text { the hybrid W33 x W266, crossed with } \\
\text { AYSYN83 }\end{array}$ \\
\hline
\end{tabular}

${ }^{2}$ Descriptions were compiled from field notebooks, release notices sent to agricultural experiment stations, and opinions of W.H. Gabelman. When color is mentioned, it refers to interior color. Aster yellows is caused by a mycoplasma-like organism vectored by the aster leafhopper, Macrosteles fascifrons stal. Foliar blights (alternaria and cercospora) are caused by the pathogens Alternaria radicina Meier et al. or Alternaria dauci (Kuhn, Groves, and Skolko) and Cercospora carotae (Pess.), respectively. Rhizoctonia is caused by the fungi Rhizoctonia carotene Rader and Rhizoctonia solani Kuhn.

"All lines with the designation "A" are petaloid-sterile, with the exception of W93A, which is brown-anther-sterile.

"All inbred lines with the designation "B" are maintainer genotypes.

"All lines with the designation "C" are restorer gentoypes.

"This inbred line, synthetic, or hybrid not released. 